\title{
Physicochemical and microbiological characteristics of El-Guedid from meat of different animal species
}

\author{
Roumeila Bader ${ }^{\mathrm{a}}$, Samira Becila ${ }^{\mathrm{a}, *, 1}$, Philippe Ruiz ${ }^{\mathrm{b}}$, Fairouz Djeghim ${ }^{\mathrm{c}}$, Ibtissem Sanah ${ }^{\mathrm{a}}$, \\ Abdelghani Boudjellal ${ }^{\mathrm{a}}$, Philippe Gatellier ${ }^{\mathrm{d}}$, Stéphane Portanguen ${ }^{\mathrm{d}}$, Régine Talon ${ }^{\mathrm{b}}$, Sabine Leroy ${ }^{\mathrm{b}}$ \\ ${ }^{\text {a }}$ Equipe MaQuaV, Laboratoire BioQuAI, Institut de Nutrition d'Alimentation et des Technologies Agro-Alimentaires (INATAA), Université des Frères Mentouri Constantine \\ 1, 25000, Algeria \\ ${ }^{\mathrm{b}}$ Université Clermont Auvergne, INRAE, MEDIS, Clermont-Ferrand 63000, France \\ ${ }^{\mathrm{c}}$ Equipe Elaboration et Transformation de Produits Agro-Alimentaires (T.E.P.A.), Laboratoire de Nutrition et Technologie Alimentaire (L.N.T.A.). INATAA, 25000, Algeria \\ ${ }^{\mathrm{d}}$ INRAE, UR370 Qualité des Produits Animaux, F-63122 Saint Genès-Champanelle, France
}

\section{A R T I C L E I N F O}

\section{Keywords:}

El-Guedid

Dry-salted meat product

Lactic acid bacteria

Coagulase negative staphylococci

\begin{abstract}
A B S T A C T
El-Guedid is an Algerian traditional meat-based product that is prepared from red meats. It belongs to the wide diversity of salted/dried meat products. This study described the physicochemical and microbiological properties of different products from four animal origins and during all the conservation. Results indicated that these products were mainly characterized by a low moisture with an average decrease of water content between $15.6 \%$ and $16.3 \%$ for all the samples, and a decrease in water activity ranging from 0.66 to 0.68 , while the salt content ranged from 8.8 to $19.3 \%$. A decrease in $\mathrm{pH}$ values oscillated from (6.3-6.4) to reach (5.2-5.5) at T0 and T365 consecutively, in all the samples. Microbial analyses revealed the absence of pathogenic bacteria such as Listeria and Salmonella but the sporadic contamination by Staphylococcus aureus up to one month of ripening. Lactic acid bacteria and coagulase negative staphylococci were the dominant populations in El-Guedid with Leuconostoc mesenteroides, Lactobacillus sakei, and Staphylococcus saprophyticus as the main species identified. All these populations decreased along the process and reached low levels (2 log CFU/g) at the end of storage (365 days). The drastic drying of El-Guedid led to safe traditional meat product that could promote its production.
\end{abstract}

\section{Introduction}

Ethnic products are part of the gastronomic and cultural heritage that promote the local, regional or national identity in countries. Recipes with ancestral know-how are transmitted from generation to generation and perpetuate the tradition. Traditional meat products are part of this ethnic products (Gagaoua \& Boudechicha, 2018). Only a few traditional meat products (not all listed) are available in Algeria and they have remained confined to their geographical nests. Unfortunately, many of them are on the verge of extinction, for various reasons, including a change in eating habits. Recently, an overview documented the 32 most known of the ethnic meat products in North African and Mediterranean countries (Gagaoua \& Boudechicha, 2018). They were grouped into five categories according to their process, i) salted and/or marinated products, ii) dried products, iii) fermented semidried/dried products, iv) smoked products and V) cooked or candied products. El-Guedid is one of these ethnic products and belongs to the category of dried products. El-Guedid, also called «el khlî», is a traditional processed meat product very widespread, especially in mountainous areas. During the religious celebration of "Aid Al Adha", each family has a large amount of meat that could not be consumed in a few days, so it is transformed in cured products, which can be stored in ambient temperature for a long time without being damaged or dangerous for the consumer health (Gagaoua \& Boudechicha, 2018). ElGuedid is prepared throughout the Algerian territory from red meat: sheep and beef mainly, and in sub-dry areas from goat and camel meat. Usually, the raw meat is cut into strips, seasoned abundantly with salt and spices sometimes and either dry or brine salted (Gagaoua \& Boudechicha, 2018). The meat is then exposed to the open air in a clean place until it dries completely under the sun for a period from one to several weeks (Benlacheheb et al., 2019; Essid, Ismail, Ahmed, Ghedamsi, \& Hassouna, 2007; FAO, 1990). The sun-drying method is considered as a cheap way of meat conservation that could be done at the domestic or farm level for quick and uncomplicated preservation of

\footnotetext{
* Corresponding author.

E-mail address: samira.becila@umc.edu.dz (S. Becila).

${ }^{1}$ Postal address: INATAA, 7ème Km route Aïn Smara, Constantine, 25,000, Algérie.
} 
large amounts of meat, which cannot be consumed immediately or stored properly. During this operation, El-Guedid reached a low water activity $\left(a_{\mathrm{w}}\right)$ from 0.6 to 0.7 (Bennani, Zenati, Faid, \& Ettayebi, 1995). In relation with this low $\mathrm{a}_{\mathrm{w}}$ and presence of salt, staphylococci are frequently numerated (Benlacheheb et al., 2019; Bennani, Faid, \& Bouseta, 2000). In Tunisian Guedid, Staphylococcus xylosus was isolated and was characterized for its lipolytic activity (Essid et al., 2007).

El-Guedid is preferably kept in sealed jars, sheltered from air and moisture. This way of preserving the meat gives its particular taste. During this ripening period, the product develops a strong flavor, due to lipolysis of fat and proteolysis that release fatty and amino acids, which contribute to its organoleptic quality (Bennani et al., 2000). For consumption, El-Guedid is softened and desalted by immersion in water for $24 \mathrm{~h}$ before using it as ingredient of several traditional dishes, such as couscous (Gagaoua \& Boudechicha, 2018).

El-Guedid belongs to the wide diversity of salted/dried meat products that could be also sometimes smoked such as biltong in South Africa (Petit, Caro, Petit, Santchurn, \& Collignan, 2014), kilishi in Nigeria (Kalilou, Collignan, \& Zakhia, 1998), boucané in Réunion Island (Poligne, Collignan, \& Trystram, 2001), kitoza in Madagascar (Ratsimba et al., 2017; Ratsimba et al., 2019), jerky in United States and charqui in South America (Pinto, Ponsano, Franco, \& Shimokomaki, 2002). All these products shared low water activity, ranging from 0.60 to 0.90 .

Very few studies have been conducted on Algerian traditional meat products. In this study, different El-Guedid samples, made from four meat types (sheep, beef, goat, and camel) in four different areas in Algeria in a traditional way by different producers, were characterized. The choice of the areas was made according to most consumed meat in each of them, and taking into consideration the dominant animal flock. Our objective was to study the evolution of physicochemical and microbiological characteristics of these samples during the entire conservation period of up to 1 year. Our research focused on the characterization and preservation of meat products from the Algerian terroir in order to promote their production. These products are not only a cultural asset, but also an economic resource that must be protected.

\section{Materials and methods}

\subsection{Manufacturing and sampling}

El-Guedid samples were prepared from different types of raw red meats derived from beef, sheep, goat and camel in the area of Algiers, Constantine, Oum El Bouaghi and Ouargla in Algeria, respectively. For each animal species, three batches of $4 \mathrm{~kg}$ each were made by three different producers located in a same geographic area and produced at the same time (same day or a few days later). The samples were prepared according to the traditional manufacturing process (Fig. 1). In brief, the fresh meat was sliced into long thin pieces $(3-7 \mathrm{~cm}$ in length, $1-2 \mathrm{~cm}$ in thickness), abundantly dry-salted (50 $\mathrm{g} / \mathrm{kg}$ of sodium chloride), drained and then suspended for sun-drying until it was completely dried. The drying process lasted 7 days according to the outside temperature (between 15 and $20^{\circ} \mathrm{C}$ ). Afterward, El-Guedid was stored in jars at room temperature (mainly varying between 15 and $25{ }^{\circ} \mathrm{C}$ ) in a dry place with moderate temperature fluctuations. Each batch was sampled at different times of the process: fresh meat (T0), after 1 month (T30), 3 months (T90), 6 months (T180) and one year of storage (T365). A total of 60 samples were analyzed.

\subsection{Physicochemical analysis}

Physicochemical analyses were performed on the 60 samples of ElGuedid between T0 and T365. All measurements were determined in duplicate or triplicate for each sample. The $\mathrm{pH}$ of the samples was measured using a pH meter (model HI 9321, Hanna Instruments) after mixing $10 \mathrm{~g}$ of sample in $90 \mathrm{~mL}$ of distilled water according to Lorenzo,

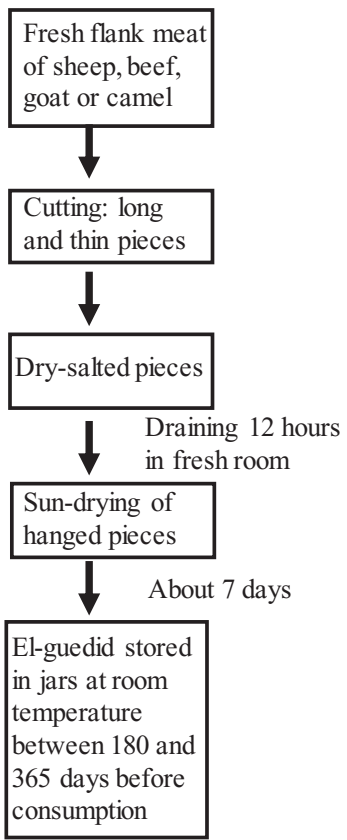

Fig. 1. Traditional Algerian diagram of preparation of El-Guedid.

García Fontán, Franco, and Carballo (2008). The sodium chloride content was calculated from the sodium concentration measured by ion chromatography as described by Mirade et al. (2020) after homogenization of $0.5 \mathrm{~g}$ of sample with $10 \mathrm{~mL}$ of ultrapure water. Moisture content (\%) was determined by drying $5 \mathrm{~g}$ of sample in an oven at $105{ }^{\circ} \mathrm{C}$ until their weight was constant for $24 \mathrm{~h}$, and then cooling it for one hour in the desiccator (Petit et al., 2014). The water activity $\left(\mathrm{a}_{\mathrm{w}}\right)$ of samples was measured with an AW-Sprint TH-500 (Novasina, Precisa, France). This instrument is calibrated with certified standards with the following $\mathrm{a}_{\mathrm{w}}$ values: $0.11 ; 0.33 ; 0.53 ; 0.75 ; 0.90$ and 0.98 . Two to $5 \mathrm{~g}$ of sample in powder form were weighed and placed in the measuring cell. The equilibrium state is checked using the Ovasina Novalog software, and the $a_{w}$ value recorded corresponds to the extension of the asymptote of the curve at the y-axis.

Fat content was determined according to the Soxhlet standard method adapted to meat by Komprda et al. (2012) using hexane as a solvent by percolation at $104{ }^{\circ} \mathrm{C}$ for one hour, followed by evaporation and then a desiccation. Lipid oxidation of samples was evaluated by measuring 2-thiobarbituric acid reactive substances (TBARS) according to the method of Mercier, Gatellier, Viau, Remignon, and Renerre (1998). It was measured on $1 \mathrm{~g}$ of powdered sample prepared from $20 \mathrm{~g}$ of sample homogenized in liquid nitrogen into powder. The results were expressed as $\mathrm{mg}$ of malondialdehyde (MDA) per $\mathrm{Kg}$ of meat. Protein carbonyl content is used as a measure of protein oxidation and was detected by reactivity with 2,4 dinitrophenylhydrazine (DNPH) as described by Oliver, Ahn, Moerman, Goldstein, and Stadtman (1987) with slight modifications (Mercier et al., 1998). The results were expressed as nmoles of DNPH fixed per mg of protein.

\subsection{Microbiological analysis}

Twenty-five grams of each sample was transferred to $225 \mathrm{~mL}$ of Tryptone Water (Difco ${ }^{\mathrm{TM}}$, Becton, Dickinson and Company, Le Pont de Claix, France) and homogenized for $4 \mathrm{~min}$ with a Stomacher (Bagmixer 400, Interscience, Saint-Nom la Bretèche, France). Decimal dilutions in Tryptone Water were then prepared in duplicate for all samples. $1 \mathrm{~mL}$ or $0.1 \mathrm{~mL}$ aliquot of appropriate dilutions was poured or spread in duplicate onto the corresponding selective media to enumerate the microorganisms. Total aerobic counts were enumerated on Plate Count Agar (PCA, Fisher Scientific Bioblock, Illkirch, France), incubated at 
Table 1

Evolution of $\mathrm{pH}$ during the ripening of El-Guedid samples from meat of different animal species.

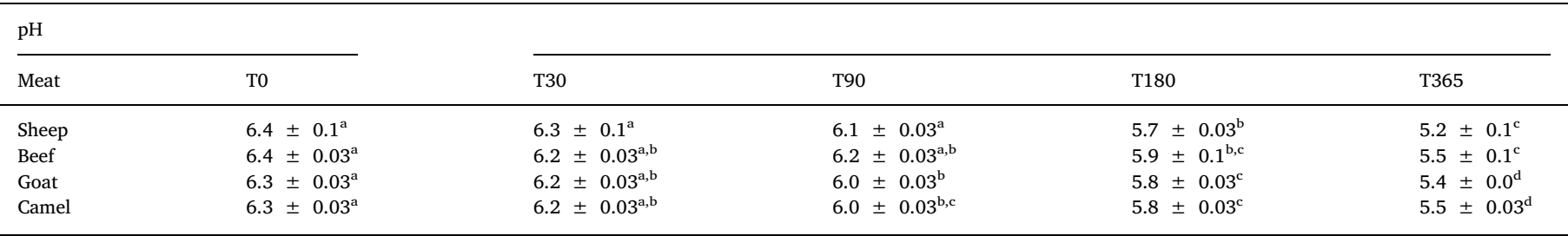

T0, fresh cut meat. T30, T90, T180, T365: 30, 90, 180, 365 days of ripening, respectively.

Mean values \pm standard errors. Different letters $\left({ }^{\mathrm{a}, \mathrm{b}}, \ldots\right)$ within the same row indicate statistical significant difference $(p<0.05)$.

$30{ }^{\circ} \mathrm{C}$ for $72 \mathrm{~h}$. Coliforms were enumerated on Violet Red Bile Lactose agar (VRBL, Fisher Scientific Bioblock), incubated for $24 \mathrm{~h}$ at $30^{\circ} \mathrm{C}$ or $44{ }^{\circ} \mathrm{C}$ for total and fecal coliforms, respectively. Violet Red Bile Glucose agar (VRBG, Fisher Scientific Bioblock) was used for the enumeration of enterobacteria after incubation at $37{ }^{\circ} \mathrm{C}$ for $24 \mathrm{~h}$. Lactic acid bacteria (LAB) were enumerated on Man Rogosa Sharp agar (MRS, Merck, Darmstadt, Germany) supplemented with nalidixic acid $(40 \mathrm{mg} / \mathrm{L})$ (Sigma-Aldrich, Steinheim, Germany) to inhibit Gram-negative bacteria and delvocid (200 mg/L) (Gist-Brocades, Netherlands) to inhibit yeast and mould after incubation for $2-3$ days at $30^{\circ} \mathrm{C}$ in a jar under modified atmosphere (Anaerocult $\mathrm{A}^{\oplus}$, Merk). Coagulase negative staphylococci (CNS) were counted on Mannitol Salt Agar (MSA, Fisher Scientific Bioblock) incubated for $24 \mathrm{~h}-48 \mathrm{~h}$ at $30{ }^{\circ} \mathrm{C}$. Yeasts and molds were determined on Yeast Extract Glucose Chloramphenicol agar (YCG, Sigma-Aldrich) incubated at $25{ }^{\circ} \mathrm{C}$ during 3-5 days. Staphylococcus aureus was enumerated on Baird-Parker medium supplemented with Tellurite Yolk Egg (Merk) after incubation of $24 \mathrm{~h}-48 \mathrm{~h}$ at $37^{\circ} \mathrm{C}$. The detection of Listeria monocytogenes was performed from $25 \mathrm{~g}$ of samples, which were enriched in half-Fraser broth (Oxoid, Basingstoke, UK) for $24 \mathrm{~h}$ at $30^{\circ} \mathrm{C}$ and then in Fraser broth (Oxoid) for $48 \mathrm{~h}$ at $37{ }^{\circ} \mathrm{C}$. After both enrichments, samples were streaked onto selective Palcam agar plates (Oxoid) incubated for $24 \mathrm{~h}-48 \mathrm{~h}$ at $37{ }^{\circ} \mathrm{C}$. Salmonella were detected by a presence-absence test. First, $25 \mathrm{~g}$ of samples were homogenized in $225 \mathrm{~mL}$ of Buffered Peptone Water (Oxoid), and incubated for $24 \mathrm{~h}$ at $37{ }^{\circ} \mathrm{C}$. After incubation, $1 \mathrm{~mL}$ was transferred to $10 \mathrm{~mL}$ of Tetrathionate broth with iodine (Oxoid), and incubated at $37{ }^{\circ} \mathrm{C}$ for $24 \mathrm{~h}$. Then, a loop full of broth was plated onto Hektoen medium (Merck) and incubated at $37{ }^{\circ} \mathrm{C}$ for $24 \mathrm{~h}$. The presence of anaerobic sulfite-reducing bacteria (SRA) were determined in tubes. $1 \mathrm{~mL}$ of homogenized sample was heat-treated at $80{ }^{\circ} \mathrm{C}$ for $10 \mathrm{~min}$ in order to kill vegetative bacteria and then $20 \mathrm{~mL}$ of Meat Liver agar (Merck), cooled to $45{ }^{\circ} \mathrm{C}$, was added. The tubes were incubated $48 \mathrm{~h}$ at $37^{\circ} \mathrm{C}$.

\subsection{Molecular identification of $L A B$ and CNS}

For each sample, 3 to 5 colonies on countable plates of MRS and MSA, representative of the different colony morphologies, were picked up and streaked over the surface of MRS and BHI (Difco ${ }^{\mathrm{TM}}$, Becton, Dickinson and Company) agar plates, respectively and incubated at $30{ }^{\circ} \mathrm{C}$ for $24 \mathrm{~h}$ and $48 \mathrm{~h}$, respectively. One colony picked from the agar plate of each isolate was transferred in appropriate broth, MRS or BHI, and incubated. Total bacteria DNA was isolated from $1 \mathrm{~mL}$ of culture using the Wizard genomic DNA purification kit (Promega, Charbonnières-les-Bains, France). Two different strategies were used for screening and then identifying bacteria isolated either from MRS or from MSA medium.

DNA of the isolates from MRS medium (presumptive LAB) were subjected to randomly amplified polymorphic DNA-polymerase chain reaction fingerprint analysis using as a primer the M13 core sequence (RAPD-PCR M13) as described by Rossetti and Giraffa (2005) in order to reduce genotypic redundancy. DNA of strains representative of each fingerprint were chosen for further species-specific PCR identification targeted to $16 \mathrm{~S}$ rRNA genes. The $16 \mathrm{~S}$ rRNA region was amplified with
27F and 967R universal primers. The PCR products after being purified using QIAquick PCR Purification Kit (Quiagen, Courtaboeuf, France) were sequenced by Eurofins Genomics (Ebersberg, Germany). Identification was proposed from alignments searches with NCBI Nucleotide Collection NR using BLAST program (http://blast.ncbi.nlm.nih.gov/ Blast.cgi) and with EzBioCloud $16 \mathrm{~S}$ database (http://eztaxon-e. ezbiocloud.net).

DNA of the isolates from MSA medium (presumptive CNS) were subjected to multiplex PCR allowing the identification of the Staphylococcus genus and of the $S$. epidermidis, S. saprophyticus, $S$. xylosus and $S$. aureus species, as described by Corbière Morot-Bizot, Talon, and Leroy (2004). Then, DNA of the strains belonging to Staphylococcus genus but unidentified at the species level by multiplex PCR was subjected to species-specific PCR identification targeted to 16S rRNA genes as described above.

\subsection{Statistical analysis}

The data were analyzed with R 3.6.1 (R Core Team, 2014), and first checked for normal distribution and homogeneity of variances before one-way ANOVA global analysis. The results were presented as means \pm SE (standard errors). In addition, many pairwise comparisons ( 2 per 2 ) using the Student's $t$-test were realized between each time and meat type. Moreover, linear discriminant analysis (LDA) in addition to Principal Component Analysis (Dray \& Dufour, 2007) was carried out in order to study the evolution and the correlation of physicochemical variables by meat type and time.

\section{Results}

\subsection{Evolution of physicochemical characteristics of El-Guedid samples during ripening}

The results of the physicochemical analyses are shown in Tables 1-5. A significant decrease in $\mathrm{pH}$ was observed throughout the process for all type meats (Table 1 ). The amplitude in the $\mathrm{pH}$ drop ranged from 0.8 to $1.2 \mathrm{pH}$ unit, with the lowest amplitude for the camel samples and the highest for the sheep ones. There was no significant difference between $\mathrm{pH}$ of the meat of different animal species whatever the time of

Table 2

Sodium chloride concentrations of El-Guedid samples from meat of different animal species.

\begin{tabular}{lll}
\hline \multicolumn{3}{l}{$\mathrm{NaCl} \%$} \\
\hline Meat & $\mathrm{T} 30$ & $\mathrm{~T} 180$ \\
Sheep & $6.8 \pm 1.8^{\mathrm{A}, \mathrm{B}}$ & $8.8 \pm 2.9^{\mathrm{A}, \mathrm{C}}$ \\
Beef & $7.9 \pm 1.6^{\mathrm{A}, \mathrm{B}}$ & $13.1 \pm 2.1^{\mathrm{A}, \mathrm{B}}$ \\
Goat & $15.9 \pm 3.5^{\mathrm{A}}$ & $19.3 \pm 1.4^{\mathrm{B}}$ \\
Camel & $5.2 \pm 0.4^{\mathrm{B}}$ & $10.3 \pm 2.8^{\mathrm{A}, \mathrm{C}}$ \\
\hline
\end{tabular}

T30, T180: 30, 180 days of ripening, respectively.

Mean values \pm standard errors. Different letters $\left({ }^{\mathrm{A}, \mathrm{B}, \mathrm{C}}\right)$ within the same column indicate statistical significant difference $(p<0.05)$. 
Table 3

Evolution of moisture and water activity during the ripening of El-Guedid samples from meat of different animal species.

\begin{tabular}{|c|c|c|c|c|c|}
\hline Meat & T0 & Т30 & T90 & $\mathrm{T} 180$ & T365 \\
\hline \multicolumn{6}{|c|}{ Moisture (\%) } \\
\hline Sheep & $27.9 \pm 1.0^{\mathrm{a}}$ & $16.2 \pm 1.0^{\mathrm{b}}$ & $15.4 \pm 0.8^{\mathrm{b}}$ & $12.3 \pm 0.4^{\mathrm{b}}$ & $11.8 \pm 0.3^{\mathrm{b}}$ \\
\hline Beef & $27.9 \pm 0.7^{\mathrm{a}}$ & $18.8 \pm 0.8^{\mathrm{b}}$ & $16.7 \pm 0.5^{\mathrm{b}, \mathrm{c}}$ & $14.1 \pm 0.7^{\mathrm{b}, \mathrm{c}}$ & $12.3 \pm 0.4^{\mathrm{c}}$ \\
\hline Goat & $27.6 \pm 0.7^{\mathrm{a}}$ & $20.8 \pm 1.3^{\mathrm{a}, \mathrm{b}}$ & $16.2 \pm 1.1^{\mathrm{b}, \mathrm{c}}$ & $13.6 \pm 1.0^{\mathrm{b}, \mathrm{c}}$ & $11.3 \pm 0.4^{\mathrm{c}}$ \\
\hline Camel & $29.8 \pm 0.6^{\mathrm{a}}$ & $25.6 \pm 1.5^{\mathrm{a}, \mathrm{b}}$ & $18.8 \pm 1.2^{\mathrm{b}, \mathrm{c}}$ & $14.8 \pm 0.7^{c}$ & $14.1 \pm 0.5^{\mathrm{c}}$ \\
\hline \multicolumn{6}{|c|}{ Water activity } \\
\hline Sheep & $0.985 \pm 0.001^{\mathrm{a}}$ & $0.675 \pm 0.013^{\mathrm{b}, \mathrm{A}, \mathrm{B}}$ & $0.671 \pm 0.002^{\mathrm{b}, \mathrm{A}, \mathrm{B}}$ & $0.660 \pm 0.045^{b}$ & $0.669 \pm 0.002^{\mathrm{b}}$ \\
\hline Beef & $0.985 \pm 0.001^{\mathrm{a}}$ & $0.670 \pm 0.008^{\mathrm{b}, \mathrm{A}, \mathrm{B}}$ & $0.661 \pm 0.007^{\mathrm{b}, \mathrm{A}, \mathrm{C}}$ & $0.681 \pm 0.017^{\mathrm{b}}$ & $0.655 \pm 0.010^{\mathrm{b}}$ \\
\hline Goat & $0.987 \pm 0.001^{\mathrm{a}}$ & $0.718 \pm 0.011^{\mathrm{b}, \mathrm{A}}$ & $0.705 \pm 0.006^{\mathrm{b}, \mathrm{B}}$ & $0.687 \pm 0.020^{\mathrm{b}}$ & $0.687 \pm 0.007^{b}$ \\
\hline Camel & $0.985 \pm 0.002^{\mathrm{a}}$ & $0.625 \pm 0.029^{\mathrm{b}, \mathrm{B}}$ & $0.630 \pm 0.014^{\mathrm{b}, \mathrm{C}}$ & $0.623 \pm 0.016^{\mathrm{b}}$ & $0.675 \pm 0.017^{b}$ \\
\hline
\end{tabular}

T0, fresh cut meat. T30, T90, T180, T365: 30, 90, 180, 365 days of ripening, respectively.

Mean values \pm standard errors. Different letters $\left({ }^{\mathrm{a}, \mathrm{b}, \mathrm{c}}\right)$ within the same row and/or different letters $\left({ }^{\mathrm{A}, \mathrm{B}, \mathrm{C}}\right)$ within the same column indicate statistical significant difference $(p<0.05)$.

ripening.

Variable concentrations of sodium chloride were analyzed at T30 and T180 between El-Guedid samples manufactured from meat of different animal species but also within samples of the same meat as shown by the high standard deviations (Table 2). This variability inside the same meat was explained by manufacturing of batches by three different small producers. This variability within and between samples explained that no clear statistical difference was observed between the types of meat and no statistical difference was found between the two ripening times.

The moisture content and the water activity of the samples decreased along the time for all the samples (Table 3). An average decrease of water content between $15.6 \%$ and $16.3 \%$ was assayed for all the samples during the ripening. A significant water loss was measured after 30 days of conservation for sheep and beef meats with $11.7 \%$ and $9.1 \%$, respectively. While for camel and goat meats, a significant decrease in water content was noted after 90 days of ripening. Concomitantly, the water activity of the samples strongly decreased especially during the first 30 days of maturation. Very low water activities were measured at this time ranging from 0.625 to 0.718 . Significant differences were only noted between the meat samples after 30 and 90 days of ripening.

Fat content was low for all raw meats (T0) of different animal species, ranging from 3.2 to $4.8 \mathrm{~g} / 100 \mathrm{~g}$ dry mater (Table 4). Higher fat percentage was noticed for sheep and beef meats during the ripening but not for goat and camel meats certainly in relation with the loss of water. Significant differences were noted between the meats of different animal species after 90 days with sheep meat having the highest fat content at the end of ripening.

Thiobarbituric values are correlated to oxidative lipid changes of the meat samples while carbonyls are correlated to protein oxidation (Table 5). There was no effect of the origin of meat on the oxidation, whatever the ripening time. A significant increase in lipid and protein oxidation was noted for beef samples while for sheep only an increase in protein oxidation was noted.
Table 5

Oxidation level during the ripening of El-Guedid samples from meat of different animal species.

\begin{tabular}{|c|c|c|c|c|c|}
\hline Meat & T0 & T30 & T90 & T180 & T365 \\
\hline \multicolumn{6}{|c|}{ Tbars $(\mathrm{mg} / \mathrm{MDA} / \mathrm{Kg})$} \\
\hline Sheep & $1.1 \pm 0.3$ & $2.6 \pm 1.0$ & $3.7 \pm 1.3$ & $3.0 \pm 0.6$ & $2.4 \pm 0.8$ \\
\hline Beef & $1.4 \pm 0.2^{\mathrm{a}, \mathrm{c}}$ & $2.5 \pm 0.7^{\mathrm{a}, \mathrm{c}}$ & $8.6 \pm 1.8^{\mathrm{b}}$ & $3.1 \pm 0.4^{\mathrm{c}}$ & $2.2 \pm 0.2^{\mathrm{c}}$ \\
\hline Goat & $2.7 \pm 0.8$ & $8.5 \pm 1.9$ & $7.3 \pm 1.3$ & $4.3 \pm 1.4$ & $5.2 \pm 1.3$ \\
\hline Camel & $1.3 \pm 0.1$ & $6.2 \pm 2.9$ & $3.0 \pm 0.1$ & $2.2 \pm 0.6$ & $3.5 \pm 0.7$ \\
\hline \multicolumn{6}{|c|}{ Carbonyls (nmol/mg protein) } \\
\hline Sheep & $6.1 \pm 0.8^{\mathrm{a}}$ & ND & ND & ND & $9.9 \pm 0.6^{b}$ \\
\hline Beef & $5.7 \pm 0.5^{\mathrm{a}}$ & ND & ND & ND & $8.5 \pm 0.4^{b}$ \\
\hline Goat & $4.0 \pm 0.7$ & ND & ND & ND & $7.3 \pm 1.2$ \\
\hline Camel & $5.7 \pm 0.9$ & ND & ND & ND & $8.2 \pm 0.5$ \\
\hline
\end{tabular}

T0, fresh cut meat. T30, T90, T180, T365: 30, 90, 180, 365 days of ripening, respectively. ND: not determined. Mean values \pm standard errors. Different letters $\left({ }^{a, b}, \mathrm{c}\right)$ within the same row indicate statistical significant difference $(p<0.05)$.

Three linear discriminant analyses (LDA) were carried out to illustrate the effect of origin of meat (camel, beef, goat, sheep) and of ripening (T0, T180, T365) on the physicochemical characteristics of ElGuedid.

At T0, the first two main components explained $98.7 \%$ of the total variance with $56.9 \%$ for the first and $41.8 \%$ for the second one (Fig. 2A). The four meats were distinguished. The first component separated the goat meat from the other three because of its higher lipid oxidation and its lower water content and $\mathrm{pH}$. The second component separated the other three meats essentially on their lipid content, camel meat having the highest content, beef the lowest and sheep the intermediate level.

After 180 days of ripening, LDA analysis showed that the four meats were also discriminated, the first two components accounting for $88.3 \%$ of the variance (Fig. 2B). The first axis distinguished goat and camel meats from beef and sheep in terms of lipid content, with beef having an intermediate level and sheep the highest. The second axis separated

Table 4

Fat content of El-Guedid samples from meat of different animal species during the ripening.

Fat (\% dry matter)

\begin{tabular}{|c|c|c|c|c|c|}
\hline Meat & T0 & T30 & T90 & $\mathrm{T} 180$ & T365 \\
\hline Sheep & $3.7 \pm 0.1^{\mathrm{a}}$ & $4.1 \pm 0.2^{\mathrm{a}}$ & $7.1 \pm 0.2^{\mathrm{b}, \mathrm{A}}$ & $7.5 \pm 0.1^{\mathrm{b}, \mathrm{A}}$ & $10.0 \pm 0.2^{\mathrm{c}, \mathrm{A}}$ \\
\hline Beef & $3.2 \pm 0.1^{\mathrm{a}}$ & $4.5 \pm 0.2^{\mathrm{a}, \mathrm{b}}$ & $4.9 \pm 0.2^{\mathrm{b}, \mathrm{c}, \mathrm{B}}$ & $6.6 \pm 0.1^{\mathrm{c}, \mathrm{d}, \mathrm{A}}$ & $7.2 \pm 0.3^{\mathrm{d}, \mathrm{B}}$ \\
\hline Goat & $4.1 \pm 0.1$ & $4.2 \pm 0.1$ & $4.7 \pm 0.3^{\mathrm{B}}$ & $5.0 \pm 0.2^{\mathrm{B}}$ & $5.1 \pm 0.3^{\mathrm{B}}$ \\
\hline Camel & $4.8 \pm 0.3$ & $4.9 \pm 0.1$ & $5.1 \pm 0.3^{\mathrm{B}}$ & $5.1 \pm 0.1^{\mathrm{B}}$ & $5.4 \pm 0.3^{\mathrm{B}}$ \\
\hline
\end{tabular}

T0, fresh cut meat. T30, T90, T180, T365: 30, 90, 180, 365 days of ripening, respectively.

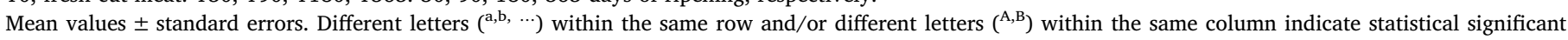
difference $(p<0.05)$. 
A

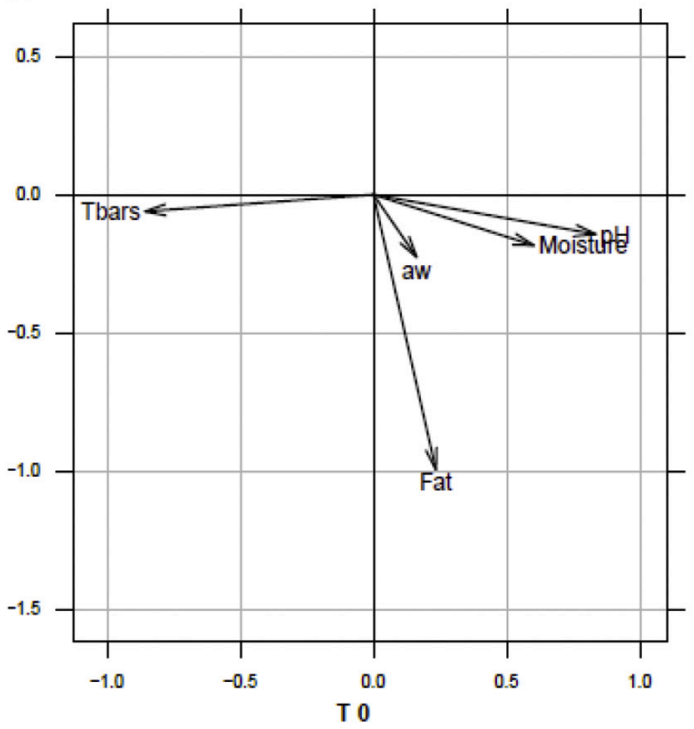

B

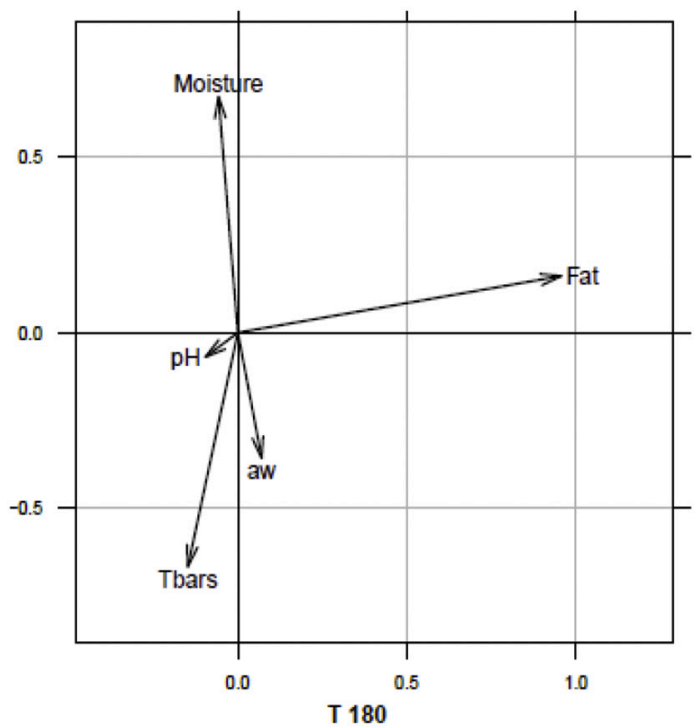

C

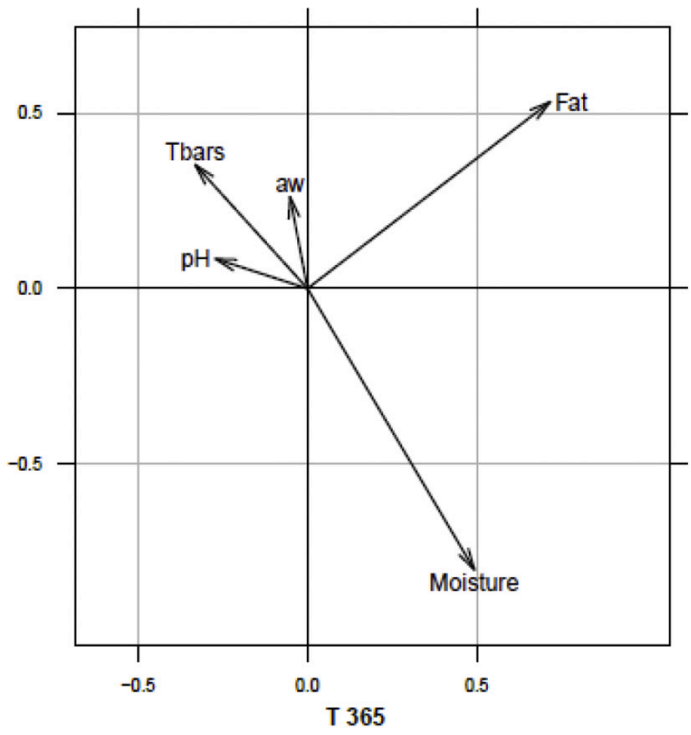

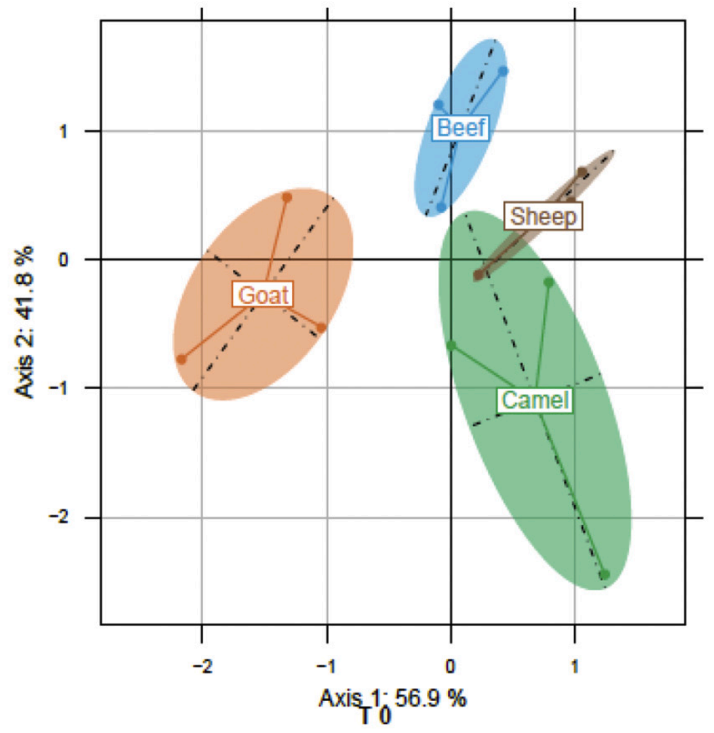
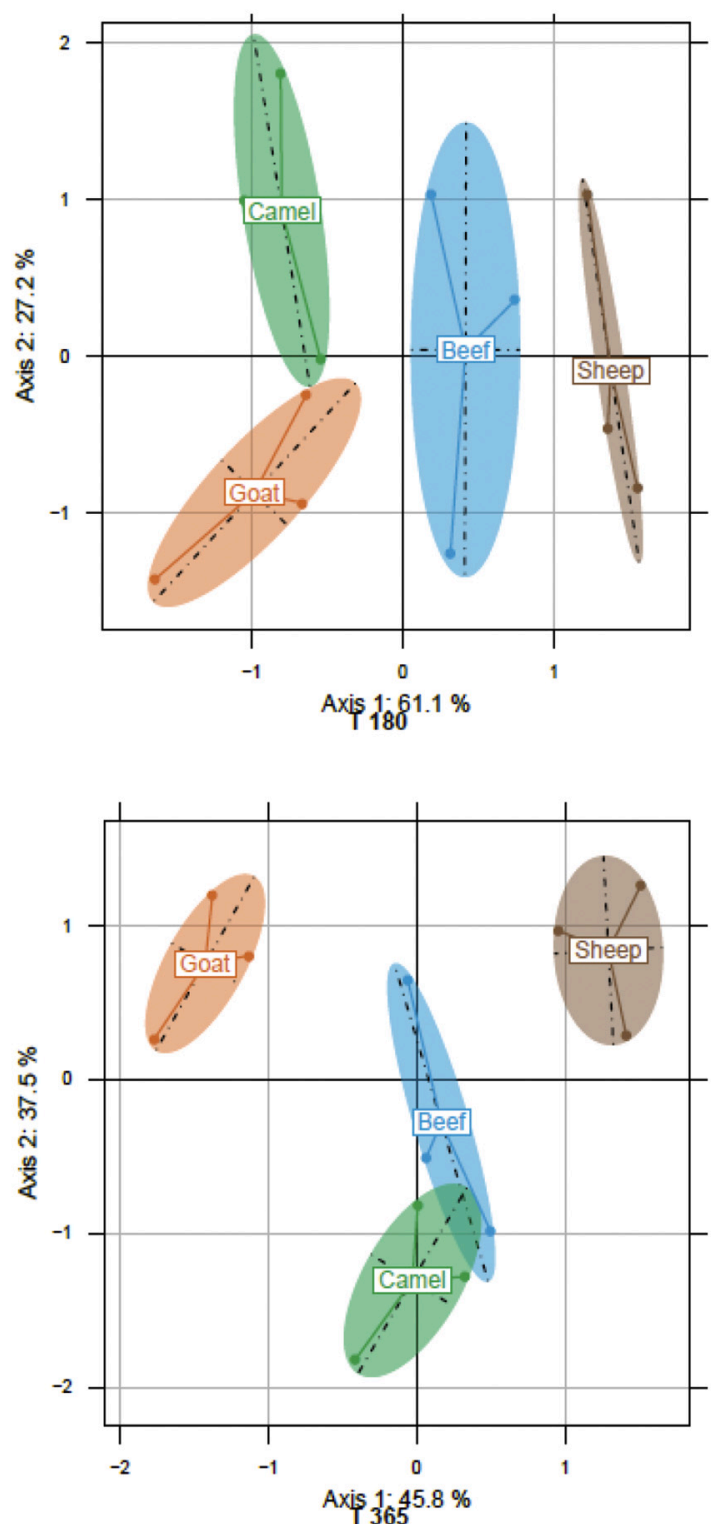

Fig. 2. Linear discriminant analysis showing the evolution and the correlation of physicochemical variables by meat type (sheep, beef, goat and camel) and time (A: T0, fresh meat, B: T180 days, C: T365 days). 
the meats according to their moisture and their lipid oxidation. Camel meat was distinguished from goat by its higher water content and lower lipid oxidation.

At the end of conservation (365 days), LDA analysis distinguished the four meats, with the first two components accounting for $83.3 \%$ of the variance (Fig. 2C). In axis 1, the meats were again separated according to their lipid content, the sheep meat having the highest content and the goat the lowest content. They were also separated by their moisture with camel meat being the wettest followed by beef. Goat meat was characterized by the highest lipid oxidation.

\subsection{Microbial characteristics of El-Guedid samples during ripening}

Microbial analyses were realized on the 60 samples, from sliced fresh meat (T0) to one year of conservation (T365). Enterobacteria, which can be considered as indicators of environmental and/or fecal contamination, were enumerated in all the fresh meat samples $(12 / 12)$ regardless of the animal species of origin. Their mean counts were $2.0 \pm 1.0 \log \mathrm{CFU} / \mathrm{g}$. From 30 days until the end of storage, all the samples, but two from sheep meat at 30 days ( 1.5 and $3.0 \log \mathrm{CFU} / \mathrm{g}$, respectively), were below the detection threshold $(<1 \log \mathrm{CFU} / \mathrm{g})$. Coliforms were below the detection threshold $(<1 \log \mathrm{CFU} / \mathrm{g}$ ) for all the samples even those of sliced fresh meat. Listeria, Salmonella and SRA were never detected. Among the bacteria representing a potential risk to consumers, $S$. aureus was only found in a few samples from sheep and beef meats. Indeed, $S$. aureus was detected in the sliced fresh meat of one ovine batch and one beef batch (2.6 $\pm 0.3 \log \mathrm{CFU} / \mathrm{g})$. It persisted up to one month of ripening in these two batches and became below the detection threshold after $(<10 \log \mathrm{CFU} / \mathrm{g})$. Yeasts and molds contaminated all samples of sliced fresh meat at average level of $3.0 \pm 0.7$ $\log \mathrm{CFU} / \mathrm{g}$. This level remained constant at T30 for the samples from sheep and beef meat $(2.7 \pm 0.7 \log \mathrm{CFU} / \mathrm{g})$ and then was below the detection threshold $(<10 \log \mathrm{CFU} / \mathrm{g}$ ). For the samples from goat and camel meat, yeasts and molds were below the detection threshold from Т30.

Total aerobic counts were on average $4.7 \pm 1.4 \mathrm{log} \mathrm{CFU} / \mathrm{g}$ for all the samples from T0 to T90. They decreased drastically at T180 to reach the detection threshold ( 1 to $1.2 \log \mathrm{CFU} / \mathrm{g}$ ). They were below the detection threshold at T365. LAB and CNS were present in all the samples from T0 to 365. The mean counts of LAB were $6.0 \pm 0.8 \mathrm{log}$ $\mathrm{CFU} / \mathrm{g}$ for the samples at T0 and decreased gradually during the ripening to reach $2.4 \pm 0.7 \log \mathrm{CFU} / \mathrm{g}$ whatever the animal species of origin of the meat (Fig. 3). The mean counts of CNS were $4.3 \pm 1.4 \mathrm{log}$ $\mathrm{CFU} / \mathrm{g}$ for the samples at $\mathrm{T} 0$, increased slightly to reach $5.6 \pm 1.1 \mathrm{log}$ $\mathrm{CFU} / \mathrm{g}$ at T30 and then decreased gradually during the storage to reach $2.3 \pm 0.8 \log \mathrm{CFU} / \mathrm{g}$ whatever the animal species of origin of the meat (Fig. 4).

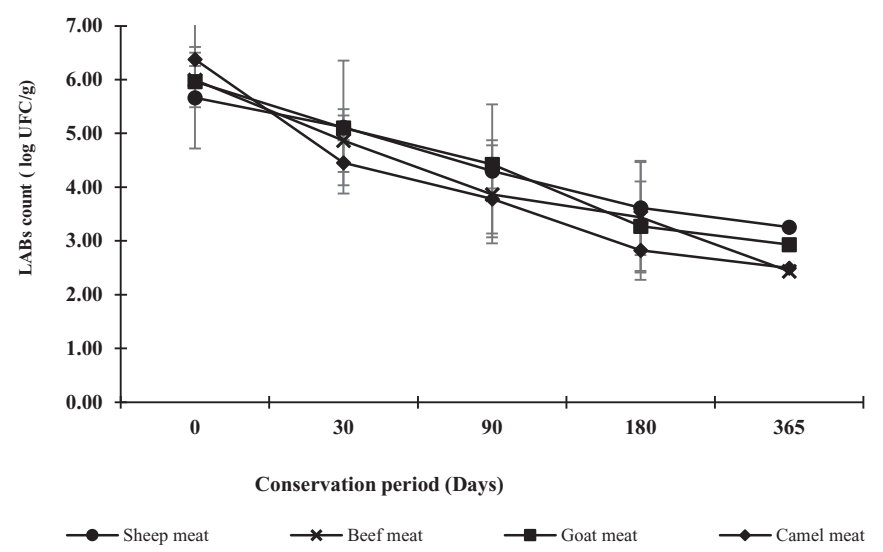

Fig. 3. Evolution of lactic acid bacterial (LAB) population in the meat samples of different animal species during the ripening process of El-Guedid.

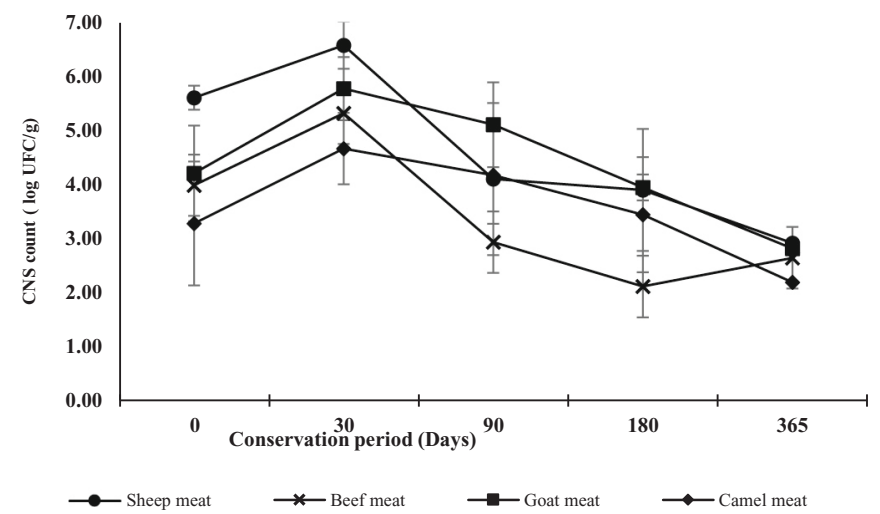

Fig. 4. Evolution of coagulase negative staphylococci (CNS) population in the meat samples of different animal species during the ripening process of ElGuedid.

A total of 160 isolates from MRS were subjected to RAPD-PCR M13. These analyses revealed a high diversity with 110 different profiles. Among the 148 isolates, one isolate representative of each profile and 2 to 3 isolates for the dominant profiles were identified after 16S rDNA gene sequencing. Among them, 132 isolates belonged to the LAB group and were identified as belonging to 7 genera: Leuconostoc (40), Lactobacillus (35), Enterococcus (20), Weissella (23), Lactococcus (11), Pediococcus (2, P. pentosaceus), and Streptococcus (1, S. parauberis). Of 40 Leuconostoc, 39 were identified as L. mesenteroides and 1 as L. citreum. Of 35 lactobacilli, 29 were identified as L. sakei and 6 as L. curvatus. In all the samples, whatever the animal species of origin of the meat, two species were concomitantly present, L. mesenteroides and L. sakei, from sliced fresh meat to T365. The other genera identified were sporadically isolated. Of 20 enterococci, 15 were identified as E. hirae, 3 as E. faecalis and 2 as $E$. thailandicus. They were present in a few samples of sheep, beef and goat meat at T90 and T365. A high species diversity was found in the Weissella genus with 6 species identified: W. viridescens (12), $W$. cibaria (3), W. thailandensis (3), W. hellenica (2), W. paramesenteroides (2) and $W$. confusa (1). They were present in some samples at different times and whatever the animal species of origin of the meat. Of 11 lactococci, 9 were identified as L. garvieae and 2 as L. formosensis. $L$. garvieae was only detected in the fresh samples from sheep and beef meat.

Sixteen isolates from MRS were identified as belonging to Staphylococcus species: S. saprophyticus (10), S. epidermidis (2), S. pasteuri (1), $S$. hominis (2) and $S$. capitis (1). Furthermore, 144 isolates from MSA were submitted to staphylococcal specific multiplex PCR. All the isolates were identified as belonging to the genus Staphylococcus, showing the population enumerated on MSA was largely dominated by staphylococci. Among them, 124 isolates belonged to $S$. saprophyticus, 4 to $S$. epidermidis and 2 to $S$. xylosus. The 14 remaining isolates were identified after 16S rDNA gene sequencing and belonged to $S$. pasteuri (5), S. hominis (4), S. capitis (3) and $S$. cohnii (2). From all samples, a total of 160 isolates of staphylococci was identified. Seven species of staphylococci were identified but $S$. saprophyticus was largely dominant (84\%). S. saprophyticus was present in all samples from sliced fresh meat to T365, whatever the animal species of origin of the meat. The remaining species identified were only sporadically isolated. S. epidermis was only present in fresh meat samples and was not detected thereafter.

\section{Discussion}

El-Guedid with a water activity ranging from 0.66 to 0.68 and a salt content from 8.8 to $19.3 \%$ can be classified as dry product. While kitoza and làcon, two other salted dried meat products, showing high water activity ( 0.83 to 0.90$)$ and low salt content $(2.4$ to $4.0 \%)$ can be considered as moist products (Lorenzo et al., 2015; Ratsimba et al., 2019). 
Finally, a third category of intermediate moisture products can be defined for charqui, jerky and dry cured ham ( $\mathrm{a}_{\mathrm{w}}$ ranging from 0.70 to 0.83) (Marušić, Vidaček, Janči, Tomislav Petrak, \& Medić, 2014; Pinto et al., 2002; Yang, Hwang, Joo, \& Park, 2009).

The initial $\mathrm{pH}$ values ( $\mathrm{pH}$ 6.3-6.4) of the fresh meats from different animal origins in this study were close to those found by Benlacheheb et al. (2019) in fresh lamb meat. These values decreased during the ripening reaching final values of 5.2 to 5.5, regardless the meat used. These results can be explained by the accumulation of lactic acid produced by lactic acid bacteria during the ripening process. Similar $\mathrm{pH}$ range was found for dry biltong, or Tunisian kaddid (Petit et al., 2014; Zaier, Essid, Chabbouh, Bellagha, \& Sahli, 2011). But our values were different to the ones found by Bennani et al. (2000) in the Moroccan kaddid ( $\mathrm{pH}=4.5$ ). For moist biltong, some kitoza products, dry salted goat meats and pork làcon, $\mathrm{pH}$ of 6.0 or up to 6.4 were measured (Marra, Salgado, Prieto, \& Carballo, 1999; Petit et al., 2014;Rahman et al., 2005; Ratsimba et al., 2019).

Salt has several roles in the final quality of the meat product, having an effect on microbiological, physicochemical and sensory characteristics (Toldra', F., 2002). Its main role is food preservation by the reduction of water activity, but it also has remarkable effects on the solubility and degradation of myofibrillar proteins (Chabbouh, Ahmed, Farhat, Sahli, \& Bellagha, 2012), and promotes the growth of halotolerant and/or halophilic microorganisms besides the inhibition of pathogen agents. Salt contents of our El-Guedid samples (beef, sheep and camel meat) were consistent with previously published data where the salt content was between 7.4 and $12.4 \%$ for Moroccan dried salted meat (Bennani et al., 1995); and our goat samples were close to làcon and charqui with high level, 16.2 and $15.5 \%$, respectively. While our samples contain more $\mathrm{NaCl}$ than other similar meat products, namely kitoza (2.6-4.1\%), kundi (0.5\%), and biltong (4.8-6.8\%) (Ratsimba et al., 2017; Alonge, 1987). It should be noted that before its consumption, El-Guedid must be desalinated in water for $24 \mathrm{~h}$, to reduce salt level.

Lipid content of El-Guedid varied according to the origin of meat, with sheep meat having the highest lipid content at the end of the conservation with $10 \mathrm{~g} / 100 \mathrm{~g}$ of dry mater. The lipid content of the three other El-Guedid from beef, goat and camel meats (5.1 to $7.2 \mathrm{~g} /$ $100 \mathrm{~g}$ dry matter) was in the same order as that of kitoza $(7.1 \mathrm{~g} / 100 \mathrm{~g}$ of dry matter), and those of salted dried goat meats ( 3.5 to $4.4 \mathrm{~g} / 100 \mathrm{~g}$ of dry matter) (Rahman et al., 2005; Ratsimba et al., 2019). Lipid oxidation was measured for all El-Guedid during the process, whatever the meat origin, the TBARS values ranging from 2.2 to $5.2 \mathrm{mg} \mathrm{MDA} / \mathrm{kg}$ at the end of the storage were close to that of pork and beef kitoza (3.5-3.7 mg MDA $/ \mathrm{kg}$ ) (Ratsimba et al., 2019). Higher TBARS values between 6 and $7 \mathrm{mg}$ MDA/kg were recorded for pork jerky samples compared to beef ones (3.5 mg MDA/kg) (Yang et al., 2009). Several studies showed that salt content might have a pro-oxidant effect toward lipids, which is due to the inhibitory action of salt on the antioxidant enzymes (catalase, superoxide dismutase and glutathione peroxidase) (Devatkal \& Naveena, 2010; Gheisari \& Motamedi, 2010; Hernandez, Park, \& Rhee, 2002; Lee, Mei, \& Decker, 1997; O'Neill, Galvin, Morrissey, \& Buckley, 1999). These enzymes in meat prevent the action of free radicals or the peroxidation products on lipids. Salt can also contain traces of heavy metals, which may participate in oxidation.

The carbonyl values of our samples are correlated with the oxidation of proteins. Salting and drying steps can have a marked effect on the oxidation of proteins in meat products (Bombrun, Gatellier, Carlier, \& Kondjoyan, 2014; Estévez, 2011). Addition of $\mathrm{NaCl}$ affected ionic strength and therefore biochemical reactions such as the protein oxidation. According to Montero, Giménez, Pérez-Mateos, and GómezGuillén (2005), $\mathrm{NaCl}$ affected the degree of assembly of myofibrillary proteins and their sensitivity to carbonylation. The $\mathrm{pH}$ drop has been shown to affect the oxidation of proteins in meat (Srinivasan, Xiong, \& Decker, 1996). The carbonyl contents measured on El-Guedid samples from meat of different animal ranged from 4.0 to $6.1 \mathrm{nmol} / \mathrm{mg}$ protein in sliced fresh meat, to reach higher levels at the end of the ripening process with 7.3 to $9.9 \mathrm{nmol} / \mathrm{mg}$ protein. These values were close to those found by Estévez, Ventanas, and Cava (2007) in Francfurt sausages (5.5-6.5 nmol/mg protein). Armenteros, Aristoy, Barat, and Toldrá (2009) reported carbonyl levels of different meat products close to our results, namely: dry ham; dried loin; dried sausage with 8.0, 8.0 and $9.0 \mathrm{nmol} / \mathrm{mg}$ protein, respectively.

Several studies have assessed the microbiology of different types of dried salted products. In our study the initial contamination (total aerobic counts) of the sliced fresh meat from different animal species was about $5 \log \mathrm{CFU} / \mathrm{g}$. This level agreed with the one already found for fresh sheep meat (Benlacheheb et al., 2019) and from fresh beef (Pinto et al., 2002) but was one log lower to the one found in raw pork meat (Lorenzo et al., 2015) and goat meat (Rahman et al., 2005). The total counts remained stable up to 90 days and then decreased along the process in the four El-Guedid studied. Enterobacteria, yeasts and molds were at low levels while lactic acid bacteria and staphylococci were the dominant population. All these populations decreased along the process and reached very low levels at the end of storage (365 days). These low levels $(2 \log \mathrm{CFU} / \mathrm{g}$ ) in all the microbiota were already mentioned for kaddid manufactured from sheep in Morocco (Bennani et al., 2000). Several surveys on biltong revealed that high levels of microorganisms were observed with levels of total counts ranging from 6 to $7 \log \mathrm{CFU} / \mathrm{g}$, of enterobacteria from 3 to $4 \log \mathrm{CFU} / \mathrm{g}$, of yeasts from 2 to $7 \mathrm{CFU} / \mathrm{g}$, of lactic acid bacteria as high as $8 \mathrm{log} \mathrm{CFU} / \mathrm{g}$ and staphylococci from 4 to $8.5 \log$ CFU/g (Naidoo \& Lindsay, 2010a, 2010b). For Khliaa Ezir, a traditional cured meat product of Algeria, the total count remained at an average of $4 \log \mathrm{CFU} / \mathrm{g}$ during the process and lactic acid bacteria constituted the dominant microbiota (Boudechicha et al., 2017).

Pathogenic bacteria can also occasionally be detected in dry salted meat products. In our study, L. monocytogenes and Salmonella were not detected while $S$. aureus was episodically detected (2.6 log CFU/g), and became below the detection threshold after one month of ripening in all El-Guedid. In fact, most of the dry meat products showed similar profile with absence of Salmonella, very few samples contaminated by Listeria and samples often contaminated by $S$. aureus with variable levels ranging from 2.0 to $4.5 \log$ CFU/g (Menéndez, Rendueles, Sanz, Santos, \& García-Fernández, 2018; Naidoo \& Lindsay, 2010a, 2010b; Ratsimba et al., 2017, 2019).

As coagulase negative staphylococci and lactic acid bacteria were the dominant populations in all the four El-Guedid studied, we identified the species. We found that the species $S$. saprophyticus was dominant in all the steps of manufacturing of the four El-Guedid. This dominance was already noticed in Kitoza a salted sun-dried meat product from pork or beef (Ratsimba et al., 2017). It was also one of the main species isolated throughout the manufacturing of dry-cured làcon (Vilar, Garcia Fontan, Prieto, Tornadijo, \& Carballo, 2000) and in traditional fermented sausages (Coton et al., 2010; Garcia Fontan, Lorenzo, Martinez, Franco, \& Carballo, 2007; Mauriello, Casaburi, Blaiotta, \& Villani, 2004; Talon \& Leroy, 2011). Seventeen species of $\mathrm{LAB}$ were identified highlighting a high diversity in the four El-Guedid studied. They belonged to the main LAB genera identified from fermented dry sausages, Lactobacillus, Pediococcus, Leuconoctoc, Weissella and Enterococcus (Albano et al., 2009; Ammor \& Mayo, 2007). Among these LAB, L. mesenteroides (30\%) and L. sakei (22\%) constituted the dominant microbiota throughout the process of the four El-Guedid. $L$. sakei is acknowledged as the most prevailing species in the microbiota of both fresh packaged meat products and traditionally fermented meat (Najjari, Ouzari, Boudabous, \& Zagorec, 2008; Bonomo, Ricciardi, Zotta, Parente, \& Salzano, 2008; Di cagno, Lopez, \& Tofalo, 2008; Cocolin, \& Ercolini, D. (Eds.)., 2007; Garcia Fontan et al., 2007; Ferreira, Barbosa, \& Silva, 2007; Leroy, Lebert, \& Talon, 2015). L. mesenteroides is often identified in fresh packaged meats and could be responsible for spoilage (Pothakos, Devlieghere, Villani, Björkroth, \& Ercolini, 2015) but is less frequently isolated in fermented meat products (Leroy et al., 2015). L. sakei and L. mesenteroides can produce 
bacteriocins that could contribute to the safety of the products (Benmechernene et al., 2014; Leroy, Lievens, \& De Vuyst, 2005). Weissella (17\%) with W. viridescens (9\%) and Enterococcus (15\%) with $E$. hirae $(11 \%)$ were the two subdominant populations in El-Guedid. Bacteria of the genus Weissella inhabit a variety of ecological niches including plants and vegetables and a variety of fermented foods with $W$. viridescens mainly associated with meat and meat products (Fusco et al., 2015). E. hirae represented $10 \%$ of the enterococcal isolates from Tunisian fresh red meat sheep and beef and was found in sausage, ham and minced meat in retail outlets in Germany (Klibi et al., 2013; Peters, Mac, Wichmann-Schauer, Klein, \& Ellerbroek, 2003). All these dominant LAB bacteria share the property to grow in the presence of salt (Marceau, Zagorec, \& Champomier-Vergés, 2003; Franz, Stiles, Schleifer, \& Holzapfel, 2003; Fusco et al., 2015).

This study is the first one where El-Guedid was characterized considering products from different animal origin and all the time of conservation. In conclusion, El-Guedid is a safe traditional meat product that responds to the criteria of sustainability.

\section{Declaration of Competing Interest}

The authors declare no conflict of interests.

\section{Acknowledgement}

This work is a collaboration between INATAA- Constantine in Algeria and INRAE- Clermont-Ferrand in France in the context of the thesis of Roumeila Bader. We are grateful to households that participated in the elaboration of all the samples, to Jean-paul Chacornac and Carine Andant for their assistance in laboratory in INRAE, UMR MEDIS, and to Claude Ferreira and Laurent Aubry in INRAE, UR QuaPA for their contribution. Finally, a special gratitude to the Algerian Ministry of Higher Education and Scientific Research for the attribution of a scholarship within the French-Algerian cooperation program : PROFAS $\mathrm{B}+$ (B/COOPERATION).

\section{References}

FAO (1990). Manual of simple methods of meat preservation. FAO Animal Production and Health Paper No. 79. Rome: FAO.

Albano, H., van Reenen, C. A., Todorov, S. D., Cruz, D., Fraga, L., Hogg, T., \& Teixeira, P. (2009). Phenotypic and genetic heterogeneity of lactic acid bacteria isolated from "Alheira", a traditional fermented sausage produced in Portugal. Meat Science, 82(3), 389-398. https://doi.org/10.1016/j.meatsci.2009.02.009.

Alonge, D. O. (1987). Factors affecting the quality of smoke-dried meats in Nigeria. Acta Alimentaria, 16(3), 263-270.

Ammor, M. S., \& Mayo, B. (2007). Selection criteria for lactic acid bacteria to be used as functional starter cultures in dry sausage production: An update. Meat Science, 76(1), 138-146. https://doi.org/10.1016/j.meatsci.2006.10.022.

Armenteros, M., Aristoy, M. C., Barat, J. M., \& Toldrá, F. (2009). Biochemical changes in dry-cured loins salted with partial replacements of $\mathrm{NaCl}$ by KCl. Food Chemistry, 117(4), 627-633. https://doi.org/10.1016/j.foodchem.2009.04.056.

Benlacheheb, R., Becila, S., Sentandreu, M. A., Hafid, K., Boudechicha, H. R., \& Boudjellal, A. (2019). El Gueddid, a traditional Algerian dried salted meat: Physicochemical, microbiological characteristics and proteolysis intensity during its manufacturing process and ripening. Food Science and Technology International, 25(4), 347-355. https://doi.org/10.1177/1082013219825892.

Benmechernene, Z., Fernández-No, I., Quintela-Baluja, M., Böhme, K., Kihal, M., CaloMata, P., \& Barros-Velázquez, J. (2014). Genomic and proteomic characterization of bacteriocin-producing Leuconostoc mesenteroides strains isolated from raw camel milk in two southwest Algerian arid zones. BioMed Research International, 2014, 853238. https://doi.org/10.1155/2014/853238.

Bennani, L., Faid, M., \& Bouseta, A. (2000). Experimental manufacturing of kaddid, a salted dried meat product: Control of the microorganisms. European Food Research and Technology, 211(3), 153-157. https://doi.org/10.1007/s002170050001.

Bennani, L., Zenati, Y., Faid, M., \& Ettayebi, M. (1995). Physico-chemical and microbiological characteristics of a dried salted meat product (Kaddid) in Morocco. Zeitschrift für Lebensmittel-Untersuchung und Forschung, 201(6), 528-532. https://doi. org/10.1007/BF01201577.

Bombrun, L., Gatellier, P., Carlier, M., \& Kondjoyan, A. (2014). The effects of low salt concentrations on the mechanism of adhesion between two pieces of pork semimembranosus muscle following tumbling and cooking. Meat Science, 96(1), 5-13.

Bonomo, M. G., Ricciardi, A., Zotta, T., Parente, E., \& Salzano, G. (2008). Molecular and technological characterization of lactic acid bacteria from traditional fermented sausages of Basilicata region (southern Italy). Meat Science, 80(4), 1238-1248. https://doi.org/10.1016/j.meatsci.2008.05.032.

Boudechicha, H. R., Nasril, I., Bennaceur, Z., Sellama, M., Hafid, K., Boudjellal, A., \& Gagaoua, M. (2017). Microbiological changes during the preparation steps of Khliaa Ezir: A traditional cured meat product of Algeria. Integrative Food, Nutrition and Metabolism, 4(6), 1-5. https://doi.org/10.15761/IFNM.1000199.

Chabbouh, M., Ahmed, S. B. H., Farhat, A., Sahli, A., \& Bellagha, S. (2012). Studies on the salting step of Tunisian kaddid meat: Experimental kinetics, modeling and quality. Food and Bioprocess Technology, 5(5), 1882-1895. https://doi.org/10.1007/s11947011-0635-2.

Cocolin, L., \& Ercolini, D. (Eds.). (2007). Molecular techniques in the microbial ecology of fermented foods. 2007Springer Science \& Business Mediahttps://doi.org/10.1007/ 978-0-387-74520-6.

Corbière Morot-Bizot, S., Talon, R., \& Leroy, S. (2004). Development of a multiplex PCR for the identification of Staphylococcus genus and four staphylococcal species isolated from food. Journal of Applied Microbiology, 97, 1087-1094. https://doi.org/10.1111/ j.1365-2672.2004.02399.x.

Core Team, R. (2014). R: A language and environment for statistical computing. Vienna, Austria: R Foundation for Statistical Computing. https://www.R-project.org/.

Coton, E., Desmonts, M. H., Leroy, S., Coton, M., Jamet, E., Christieans, S., ... Talon, R. (2010). Biodiversity of coagulase-negative staphylococci in French cheeses, dry fermented sausages, processing environments and clinical samples. International Journal of Food Microbiology, 137, 221-229. https://doi.org/10.1016/j.ijfoodmicro.2009.11. 023.

Devatkal, S. K., \& Naveena, B. (2010). Effect of salt, kinnow and pomegranate fruit byproduct powders on color and oxidative stability of raw ground goat meat during refrigerated storage. Meat Science, 85(2), 306-311. https://doi.org/10.1016/j. meatsci.2010.01.019.

Di cagno, R., Lopez, C. C., \& Tofalo, R. (2008). Comparison of the compositional, microbiological, biochemical and volatile profile characteristics of three Italian PDO fermented sausages. Meat Science, 79(2), 224-235. https://doi.org/10.1016/j. meatsci.2007.09.006.

Dray, S., \& Dufour, A. (2007). The ade4 package: Implementing the duality diagram for ecologists. Journal of Statistical Software, 22(4), 1-20. https://doi.org/10.18637/jss. v022.i04.

Essid, I., Ismail, H. B., Ahmed, S. B. H., Ghedamsi, R., \& Hassouna, M. (2007). Characterization and technological properties of Staphylococcus xylosus strains isolated from a Tunisian traditional salted meat. Meat Science, 77(2), 204-212. https:// doi.org/10.1016/j.meatsci.2007.03.003.

Estévez, M. (2011). Protein carbonyls in meat systems: A review. Meat Science, 89(3), 259-279. https://doi.org/10.1016/j.meatsci.2011.04.025.

Estévez, M., Ventanas, S., \& Cava, R. (2007). Oxidation of lipids and proteins in frankfurters with different fatty acid compositions and tocopherol and phenolic contents. Food Chemistry, 100, 55-63. https://doi.org/10.1016/j.foodchem.2005.09.009.

Ferreira, V., Barbosa, J., \& Silva, J. (2007). Characterisation of alheiras, traditional sausages produced in the north of Portugal, with respect to their microbiological safety. Food Control, 18, 436-440. https://doi.org/10.1016/j.foodcont.2005.11.011.

Fusco, V., Quero, G. M., Cho, G.-S., Kabisch, J., Meske, D., Neve, H., ... Franz, C. M. A. P. (2015). The genus Weissella: Taxonomy, ecology and biotechnological potential. Frontiers in Microbiology, 6, 155. https://doi.org/10.3389/fmicb.2015.00155.

Gagaoua, M., \& Boudechicha, H. R. (2018). Ethnic meat products of the North African and Mediterranean countries: An overview. Journal of Ethnic Foods, 5(2), 83-98. https:// doi.org/10.1016/j.jef.2018.02.004.

Garcia Fontan, M. C., Lorenzo, J. M., Martinez, S., Franco, I., \& Carballo, J. (2007). Microbiological characteristics of Botillo, a Spanish traditional pork sausage. LWT Food Science and Technology, 40, 1610-1622. https://doi.org/10.1016/j.lwt.2006.10. 007.

Gheisari, H. R., \& Motamedi, H. (2010). Chloride salt type/ionic strength and refrigeration effects on antioxidant enzymes and lipid oxidation in cattle, camel and chicken meat. Meat Science, 86(2), 377-383. https://doi.org/10.1016/j.meatsci.2010.05.020.

Hernandez, P., Park, D., \& Rhee, K. S. (2002). Chloride salt type/ionic strength, muscle site and refrigeration effects on antioxidant enzymes and lipid oxidation in pork. Meat Science, 61(4), 405-410. https://doi.org/10.1016/S0309-1740(01)00212-1.

Kalilou, S., Collignan, A., \& Zakhia, N. (1998). Optimizing the traditional processing of beef into Kilishi. Meat Science, 50(1), 21-32. https://doi.org/10.1016/S03091740(98)00012-6.

Klibi, N., Ben Said, L., Jouini, A., Ben Slama, K., López, M., Ben Sallem, R., ... Torres, C. (2013). Species distribution, antibiotic resistance and virulence traits in enterococci from meat in Tunisia. Meat Science, 93(3), 675-680. https://doi.org/10.1016/j. meatsci.2012.11.020.

Komprda, T., Kuchtik, J., Jarosova, A., Drackova, E., Zemanek, L., \& Filipcik, B. (2012). Meat quality characteristics of lambs of three organically raised breeds. Meat Science, 91(4), 499-505. https://doi.org/10.1016/j.meatsci.2012.03.004.

Lee, S. K., Mei, L., \& Decker, E. A. (1997). Influence of sodium chloride on antioxidant enzyme activity and lipid oxidation in frozen ground pork. Meat Science. 46(4), 349-355. https://doi.org/10.1016/S0309-1740(97)00029-6.

Leroy, S., Lebert, I., \& Talon, R. (2015). Microorganisms in traditional fermented meats. Fermented meat products and role of starter culture. In F. Toldra (Ed.). Handbook of fermented meat and poultry (pp. 99-105). (2nd ed.). chapter 12.

Leroy, F., Lievens, K., \& De Vuyst, L. (2005). Modeling Bacteriocin resistance and inactivation of Listeria innocua LMG 13568 by Lactobacillus sakei CTC 494 under sausage fermentation conditions. Applied and Environmental Microbiology, 71(11), 7567-7570. https://doi.org/10.1128/AEM.71.11.7567-7570.2005.

Lorenzo, J. M., Bermúdez, R., Domínguez, R., Guiotto, A., Franco, D., \& Purriños, L. (2015). Physicochemical and microbial changes during the manufacturing process of dry-cured lacón salted with potassium, calcium and magnesium chloride as a partial 
replacement for sodium chloride. Food Control, 50, 763-769. https://doi.org/10. 1016/j.foodcont.2014.10.019.

Lorenzo, J. M., García Fontán, M. C., Franco, I., \& Carballo, J. (2008). Biochemical characteristics of dry-cured lacón (a Spanish traditional meat product) throughout the manufacture, and sensorial properties of the final product. Effect of some additives. Food Control, 19(12), 1148-1158. https://doi.org/10.1016/j.foodcont.2007. 12.005.

Marceau, A., Zagorec, M., \& Champomier-Vergés, M. C. (2003). Positive effects of growth at suboptimal temperature and high salt concentration on long-term survival of Lactobacillus sakei. Research in Microbiology, 154, 37-42. https://doi.org/10.1016/ S0923-2508(02)00010-4.

Marra, A. I., Salgado, A., Prieto, B., \& Carballo, J. (1999). Biochemical characteristics of dry-cured lacón. Food Chemistry, 67, 33-37. https://doi.org/10.1016/S03088146(99)00104-1.

Marušić, N., Vidaček, S., Janči, T., Tomislav Petrak, T., \& Medić, H. (2014). Determination of volatile compounds and quality parameters of traditional Istrian dry-cured ham. Meat Science, 96(4), 1409-1416. https://doi.org/10.1016/j.meatsci. 2013.12.003.

Mauriello, G., Casaburi, A., Blaiotta, G., \& Villani, F. (2004). Isolation and technological properties of coagulase negative staphylococci from fermented sausages of southern Italy. Meat Science, 67, 149-158. https://doi.org/10.1016/j.meatsci.2003.10.003.

Menéndez, R. A., Rendueles, E., Sanz, J. J., Santos, J. A., \& García-Fernández, M. C. (2018). Physicochemical and microbiological characteristics of diverse Spanish cured meat products. CyTA-Journal of Food, 16, 199-204. https://doi.org/10.1080/ 19476337.2017.1379560.

Mercier, Y., Gatellier, P., Viau, M., Remignon, H., \& Renerre, M. (1998). Effect of dietary fat and vitamin $\mathrm{E}$ on colour stability and on lipid and protein oxidation in Turkey meat during storage. Meat Science, 48(3-4), 301-318. https://doi.org/10.1016/ s0309-1740(97)00113-7.

Mirade, P. S., Portanguen, S., Sicard, J., De Souza, J., Musavu Ndob, A., Hoffman, L. C., ... Collignan, A. (2020). Impact of tumbling operating parameters on salt, water and acetic acid transfers during biltong-type meat processing. Journal of Food Engineering, 265(109686), 1-9. https://doi.org/10.1016/j.jfoodeng.2019.109686.

Montero, P., Giménez, B., Pérez-Mateos, M., \& Gómez-Guillén, M. C. (2005). Oxidation stability of muscle with quercetin and rosemary during thermal and high-pressure gelation. Food Chemistry, 93(1), 17-23. https://doi.org/10.1016/j.foodchem.2004. 08.038 .

Naidoo, K., \& Lindsay, D. (2010a). Survival of Listeria monocytogenes, and enterotoxinproducing Staphylococcus aureus and Staphylococcus pasteuri, during two types of biltong-manufacturing processes. Food Control, 21(7), 1042-1050. https://doi.org/ 10.1016/j.foodcont.2009.12.025.

Naidoo, K., \& Lindsay, D. (2010b). Pathogens associated with biltong product and their in vitro survival of hurdles used during production. Food Protection Trends, 30(9), $532-538$.

Najjari, A., Ouzari, H., Boudabous, A., \& Zagorec, M. (2008). Method for reliable isolation of Lactobacillus sakei strains originating from Tunisian seafood and meat products. International Journal of Food Microbiology, 121, 342-351. https://doi.org/10.1016/j. ijfoodmicro.2007.11.045.

Oliver, C. N., Ahn, B., Moerman, E. J., Goldstein, S., \& Stadtman, E. R. (1987). Age related changes in oxidized proteins. Journal of Biological Chemistry, 262(12), 5488-5491. 3571220 .

O'Neill, L. M., Galvin, K., Morrissey, P. A., \& Buckley, D. J. (1999). Effect of carnosine, salt and dietary vitamin E on the oxidative stability of chicken meat. Meat Science, 52(1), 89-94. https://doi.org/10.1016/S0309-1740(98)00152-1.

Peters, J., Mac, K., Wichmann-Schauer, H., Klein, G., \& Ellerbroek, L. (2003). Species distribution and antibiotic resistance patterns of enterococci isolated from food of animal origin in Germany. International Journal of Food Microbiology, 88, 311-314. https://doi.org/10.1016/s0168-1605(03)00193-4.

Petit, T., Caro, Y., Petit, A. S., Santchurn, S. J., \& Collignan, A. (2014). Physicochemical and microbiological characteristics of biltong, a traditional salted dried meat of South Africa. Meat Science, 96(3), 1313-1317. https://doi.org/10.1016/j.meatsci.2013.11. 003.

Pinto, M. F., Ponsano, E. H. G., Franco, B. D. G. D. M., \& Shimokomaki, M. (2002). Charqui meats as fermented meat products: Role of bacteria for some sensorial properties development. Meat Science, 61(2), 187-191. https://doi.org/10.1016/ s0309-1740(01)00184-x.

Poligne, I., Collignan, A., \& Trystram, G. (2001). Characterization of traditional processing of pork meat into boucane. Meat Science, 59(4), 377-389. https://doi.org/10. 1016/S0309-1740(01)00090-0.

Pothakos, V., Devlieghere, F., Villani, F., Björkroth, J., \& Ercolini, D. (2015). Lactic acid bacteria and their controversial role in fresh meat spoilage. Meat Science, 109(2015), 66-74. https://doi.org/10.1016/j.meatsci.2015.04.014.

Rahman, M. S., Salman, Z., Kadim, I. T., Mothershaw, A., Al-Riziqi, M. H., Guizani, N., ... Ali, A. (2005). Microbial and physico-chemical characteristics of dried meat processed by different methods. International Journal of Food Engineering, 1, 1-114. https://doi.org/10.2202/1556-3758.1016.

Ratsimba, A., Leroy, S., Chacornac, J. P., Rakoto, D., Arnaud, E., Jeannoda, V., \& Talon, R. (2017). Staphylococcal ecosystem of Kitoza, a traditional Malagasy meat product. International Journal of Food Microbiology, 2017(246), 20-24. https://doi.org/10. 1016/j.ijfoodmicro.2017.02.001.

Ratsimba, A., Rakoto, D., Jeannoda, V., Andriamampianina, H., Talon, R., Leroy, S., ... Arnaud, E. (2019). Physicochemical and microbiological characteristics of kitoza, a traditional salted/dried/smoked meat product of Madagascar. Food Science \& Nutrition, 7(8), 2666-2673. https://doi.org/10.1002/fsn3.1122.

Rossetti, L., \& Giraffa, G. (2005). Rapid identification of dairy lactic acid bacteria by M13generated, RAPD-PCR fingerprint databases. Journal of Microbiological Methods, 63, 135-144. https://doi.org/10.1016/j.mimet.2005.03.001.

Srinivasan, S., Xiong, Y. L., \& Decker, E. A. (1996). Inhibition of protein and lipid oxidation in beef heart surimi-like material by antioxidants and combinations of $\mathrm{pH}$, $\mathrm{NaCl}$, and buffer type in the washing media. Journal of Agricultural and Food Chemistry, 44, 119-125. https://doi.org/10.1021/jf950385i.

Franz, C. M. A. P., Stiles, M. E., Schleifer, K. H., \& Holzapfel, W. H. (2003). Enterococci in foods -a conundrum for food safety. International Journal of Food Microbiology, 88, 105-122. https://doi.org/10.1016/S0168-1605(03)00174-0.

Talon, R., \& Leroy, S. (2011). Diversity and safety hasards of bacteria involved in meat fermentations. Meat Science, 89(3), 303-309. https://doi.org/10.1016/j.meatsci. 2011.04.029.

Toldra', F. (2002). Manufacturing of dry-cured ham. Dry-cured meat products (pp. 27-62). Trumbull, Connecticut, USA: Food \& Nutrition Press Inc.

Vilar, I., Garcia Fontan, M. C., Prieto, B., Tornadijo, M. E., \& Carballo, J. (2000). A survey on the microbiological changes during the manufacture of dry-cured Lacon, a Spanish traditional meat product. Journal of Applied Microbiology, 89, 1018-1026. https://doi. org/10.1046/j.1365-2672.2000.01210.x.

Yang, H. S., Hwang, Y. H., Joo, S. T., \& Park, G. B. (2009). The physicochemical and microbiological characteristics of pork jerky in comparison to beef jerky. Meat Science, 82(3), 289-294. https://doi.org/10.1016/j.meatsci.2009.01.029.

Zaier, A., Essid, I., Chabbouh, M., Bellagha, S., \& Sahli, A. (2011). Physico-chemical and microbial caracteristics of traditional and industrial kaddid. Palma, Balearic Island, Spain: European Drying Conference. 